\title{
Persecution to Prosecution of a Prison Activist
}

Jon Marc Taylor

I

thad been exactly one week since my promotion, when the phone on my

desk rang. In my top floor office, with a view of the bronze capitol dome shining above my IBM-486 computer, the voice told me to return to the cell house and pack my property. I was being shipped to Crossroads Correctional Center in the far northwest corner of the state - the newest nirvana in the ever-expanding Missouri Department of Corrections (DOC). My butt was literally to be on the last bus from Tombstone to Boot Hill, completing the human consignment to the 1,500-man maximum security, death fence-enclosed prison.

To say I was shocked, though not thoroughly surprised, is a mournful understatement. Two weeks earlier, my caseworker advised me that I was not on any transfer list he had seen. For three of the eighteen years of incarceration I had survived the 160-year-old Missouri State Penitentiary - recently, if not magically, rechristened the Jefferson City Correctional Center - I had only a single minor rule violation blotting my record. Though no saint walking the main line in one of the nation's most notorious prisons, I was self-assured and able to carry myself with maturity, as a convict should. With the sponsorship of family and friends, I had been lucky enough as well to complete half of a baccalaureate program via correspondence from Washington State University.

Moreover, I was an active board member of the Charitable Campaign Committee, which responsibly collected the institution's aluminium soda cans for recycling, raising over $\$ 10,000$ for donation to local charities. I was also the co-director of the prison's first annual Food for Families Campaign, collecting over 2,300 canned goods for Christmas donation to area food banks and a media liaison for the Substance Abuse Advisory Committee. In all endeavors we had successfully publicized our efforts in the media, facets of prison life in the "Show-Me" state that were rarely presented to the outside world.

My greatest achievement, however, had been advancing in two years from narrator to narration supervisor to resident director of the Center for Braille and Narration Production (CBNP). The CBNP is the oldest and most prolific prison-based program of its type in the country. Employing over twenty specially screened and highly trained prisoners, the CBNP in 1996 narrated over 65,000 pages of mostly college-level text, transcribed over 70,000 pages of Braille production, and formatted nearly 80,000 pages of large print documents for 
the state's visually impaired citizens. The indirectly supervised resident director holds the most responsible prisoner position in the entire DOC, managing the utilization of over $\$ 50,000$ in computer, printing, recording, and duplicating equipment with annual billings exceeding $\$ 70,000$. Even more importantly, the services provided by the center save the state's Rehabilitation Services for the Blind more than $\$ 1.5$ million a year in reduced production costs. For the last three years, the CBNP was an appropriation in the state's budget, for additional equipment and service upgrades. Not bad for a prisoner-run operation.

All this and yet I was to be shipped out the next morning ahead of over 700 eligible prisoners. But I knew why. The next time I answered the phone, my suspicions were confirmed.

The high-ranking prison administrator on the other end of the line commiserated with me that there was nothing to be done to stop my transfer. The order originated from the central office. "Your editorial and legislative activism," he said, "has disturbed the status quo of the powers that be and they want you as far away from the capital as possible." Some bureaucrats actually talk like this. "And Crossroads," he drawled, "is about as far as you can get from the capital!"

My transfer was the result of my persistent challenging of the state's criminal justice policies. For years now, I have been a writer researching, analyzing, and exposing successes and (mostly) failures of the correctional-industrial complex. I had earlier lobbied against the Congressional expulsion of prisoners from the Pell Grant program. During the debate, Senator Paul Simon read one of my articles into The U.S. Congressional Record. And citing me by name in a national magazine editorial, Congressman Bart Gordon attempted ineffectively to rebut my arguments. Sadly, prisoners lost that fight, but our efforts delayed the myopia of political expediency by four years.

Later, in a published Business Week letter, I had the audacity to challenge a Nobel Laureate's assumptions regarding the expansive, punitive use of incarceration. The combination of those writings generated extensive reader response, including Presidential attention.

In Missouri, I once chronicled in newspapers across the state the needless expansion of the prison system, and how the associated costs not only have dollar amounts but how they have doubled the tuition rates at the state university system in six short years. The now widely published editorial analyzing how incarceration policies drive the cost of university tuition was disseminated by the Washington-based Campaign for an Effective Crime Policy. This exposure 
- coupled with illumination of the evident hypocrisy of many politicians' "crime fighting" pronouncements - has not inured me to many of the movers and shakers in the land of the Missouri Mule.

Dr. Stephen J. Steuer, Executive Director of the international Correctional Education Association, has remarked, "it amazes me how much of a positive impact [Jon Marc] has had on corrections nationally while sitting, pen in hand, in a prison cell." Of course, whether or not my impact is "positive" depends on one's perspective.

My greatest transgression, however, was the publication and subsequent lobbying around a position paper titled "Calling for Sheepskins." The article outlined how the redirected investment of the rebate (a.k.a. kickback) from the MCI-Inmate Collect Call Phone System could refinance post-secondary education programs in Missouri prisons, which had been discontinued after the loss of Pell Grants. The original paper noted how the $\$ 3$ million in annual rebates went directly to the state's general fund, as opposed to the inmates' welfare fund as was done in all but two other states. Employing the experience gained from the national Pell Grant fight, grassroots lobbying resulted in 21 co-sponsors introducing enabling legislation in the Missouri House (H.B. 481) and bipartisan introduction in the State Senate (S.B. 336) during the first days of 1997.

Efforts to generate broad-based support for the legislation included contacting over 60 college and university presidents in the state, explaining the proposal's expansive societal benefits, and requesting that they contact their representatives urging support. Many responded - including the biggest dog on the block, University of Missouri System interim president Melvin D. George, who wrote, "we will do what we can to encourage passage so as to provide educational opportunities for prison inmates." Others were even more responsive. Donald $J$. Beckon, president of Park College, wrote to his senator in support of the legislation offering to "happily testify at any hearing as an expert witness, or do whatever else I can do."

Additional lobbying was conducted by writing to all representatives of the Catholic faith (nearly one third of the assembly), enclosing a 1996 article from U.S. Catholic magazine reporting that parishioners overwhelmingly supported tax-supported prisoner higher education. My proposed legislation, I explained, achieved the goal without requiring taxpayers' dollars. A few days after the sealed (privileged correspondence) mailing, the prison's investigator, in an 
apparent coincidental passing, commented that he "noticed" my large number of letters to the Legislature. One respondent, Representative Norman Sheldon, stated that he agreed "with the concept of [my] letter and that Post-Secondary Correctional Education is the best rehabilitative tool that can be offered as of today."

During the early hectic days of the session, the primary lobbyist for this measure was an inexhaustible, diminutive Catholic nun. After a committee hearing one moming, Sister Ruth Heaney walked the four blocks from the capitol to the prison, arranged a special visit with me (no small administrative accomplishment), and sought my immediate advice on various aspects of the issue. I was then able to return to my job, access my files, produce rebuttal fact sheets, mass-produce them, and mail them out the next morning.

Support for the legislation also came from groups both within and without the state. The Missouri Catholic Conference endorsed the measure. Julie Stewart, president of the Washington-based foundation Families Against Mandatory Minimums, offered to do whatever they could to support its passage, commenting that the proposal was a "brilliant" idea and that it was a concept her organization would "like to pursue with other states and maybe federally." The Judicial Process Commission, in their newsletter Justicia, reprinted the paper under the title of "Dialing for Diplomas," further spreading the concept across the country. International exposure for the idea was provided in a Christian Science Monitor interview concerning prisoner higher education.

While passing the Senate Committee, the legislation failed to pass the House Committee. Not only had the DOC curiously failed to support the bills, an illuminating incident occurred in a capitol stairwell minutes after the committee's vote. Initially assuming the confidence of one of the legislators, a high-ranking DOC official cryptically observed, "It's too much money." The representative then acquired the new phone contract, learning that the annual rebate had grown over 333 percent to a guaranteed annual minimum of $\$ 10$ million. With perpetual population growth, the projected rebate to the state general fund over the five-year life of the contract approaches $\$ 60$ million.

If passed, the state would not only be denied tens of millions of dollars in non-taxed revenue, but prisoners would have the opportunity to earn fully subsidized college education. To some politicians, this would be an unpalatable circumstance. The rationale - that in effect the prisoners' friends and families accepting their collect telephone calls would be financing the prisoners' 
Journal of Prisoners on Prisons, Volume 12, 2003

educations - be damned. The comment of "too much money" now made sense. As one of my astute road dogs commented on my impending transfer, "Son, you've just been shanghaied."

Exactly one week after my exile, in what was quickly understood to be the "CrossOUT" Correctional Center, my cell door was thrown open at 11:30 p.m. A sergeant stormed in, told my slumbering cell partner and myself to stand, and ordered me to submit to a strip-search. The act of removing all of one's clothing, opening one's mouth like chattel on the auction block, hefting one's scrotum to demonstrate the lack of concealment of "whatever," followed by the turning of one's naked body to the particular master of one's immediate fate, lifting the feet to expose their soles, and the final humiliation of bending over and spreading your buttocks so the offending officer can observe that you have not shoved contraband up your ass is - after nearly two decades of endurance - methodical in its redundancy. Behind bars it is a simple, brutal fact of life. I had grown used to it, if not complacent. Dignity, I have learned, resides within the spirit of the individual and not in the control of agent provocateurs, no matter how calloused or corrupt.

Not comprehending the reason for the explosive harassment, I stripped, yawned, hefted, turned my naked form to the irate officer, and lifted my feet - only to find my face pressed into the concrete wall. Yelling, "And what's this?" into my ear, the sergeant flashed a small cellophane package in my face. Screaming that $\mathrm{I}$ had tried to kick him in the head as, breaking procedure, he bent down behind me to allegedly scoop up the package, he allowed me to put on only my robe before cuffing my hands behind my back. At midnight I was marched across the prison and thrown into the hole.

An hour later, I was charged with DOC violations of \#2 assault on staff (\#1 is murder!) and \#11 possession of contraband. The officer claimed the package of contraband was 0.18 grams of marijuana, the amount found in a disposable packet of pepper. The situation was ridiculous. I nearly laughed out loud. Back at Jefferson City Correctional Center, the shift captain would have dismissed the incident for being too contrived. Facing the inconvenience of a few days in the hole, I believed the whole matter would blow over the following week.

A week later, the lone reviewing female administrator found me guilty of assault on staff, but not of possession. At the time, I had done the stand-up thing any convict would, and copped to the "evidence" to save my cellie from being tossed into segregation as well. It is the practice in such situations to lock up both residents of a cell when contraband is found if neither immediately 
claims the possession, with both being found guilty later and suffering sanctions if neither confesses. The requested Psychological Stress Evaluation (voice lie detector) had not been administered, even though DOC policy dictates its use "in extremely serious situations as deemed appropriate by the approving official." (If 30 possible additional years of prison time is not deemed "serious," I would like to know, what are the criteria?) For the next 220 days I would lose twenty pounds and nearly my sanity in the hole of "Crossout" Correctional Center.

Everyone, staff and prisoners alike, agreed the situation was a travesty. Ironically, I became a segregation trustee, while every one of my administrative. appeals was summarily denied. Truly adding insult to injury, on December 23, 1997, my Christmas present from the "Show-Me" state was the indictment for Class B felony assault and Class C felony possession. If convicted, the county's infamous hanging judge could sentence me to an additional thirty consecutive years. Even without the criminal charges, the associate superintendent told a delegation of my family that the staff assault violation would set my parole eligibility back a minimum of two to four years.

A month after my almost total isolation in the hole, State Representative Vicky Riback Wilson, indicating she had heard that I had been transferred, wrote advising me of her intent to re-file the education funding legislation in the upcoming session. The representative observed there was a strong coalition of supporters, but they needed to be organized and mobilized. "Thank you again for everything you are doing," she concluded her epistle; "I look forward to working with you." On January 15,1998 , House Bill No. 1372 was submitted for consideration. Separated from all my resources, I was powerless to offer my support. I had been silenced.

The measure eventually failed, though advancing further in the committee process than in the previous attempt.

On January 13, 1998, I was arraigned in DeKalb County Criminal Court. The sergeant testified under oath that I had complied with all orders, was not belligerent, offered no resistance, and did not even touch him. The only evidence to be presented of my "intent" to assault him was his perception that I "might be angry" for being searched. I was scheduled for trial on June $26^{\text {th }}$.

Five minutes. Five minutes - that is all. That was the entire amount of time I spent with the assigned Public Defender in February preparing for trial. A dozen multi-page letters providing information, strategic outlines, and tactical suggestions were sent to the lawyer. For instance, I learned the officer involved was notorious, described as a "cowboy" by other staff. He was already being 
sued by another prisoner in federal court for falsifying reports of a different incident. In January, he had been arrested for felony fraud. That month the DOC suspended him during an investigation of the sexual harassment and assault of at least one female officer. In April, the sergeant had his stripes taken away, and was demoted to the officer rank. And in May (for reasons I would love to hear), he resigned from the DOC. Yet I could not get my attorney to request a copy of the man's personnel file.

Never did I elicit any substantive response from the Public Defender, and only when I filed seven pro se motions ten days before the trial (one being to dismiss counsel) did I speak with her for the second time. Trial day came and went. The only reason the trial continued was that there was another case ready for presentation that day as well. If not for that substitute drama, without having deposed a single prosecution or defence witness, the Public Pretender would have had to represent me before a jury.

The state's assigned counsel would have served as the conductor on the railroad roundhouse from prison back to prison. Do not pass $\mathrm{GO}$ and collect your $\$ 200$ in this rigged "Monopoly" game, but go straight to jail. It was all just a ceremony of jeers, serving as a sort of social recycling in the age of the prison-industrial complex. "Keep the bunks filled and the dissenters quiet" is the unofficial motto of the insidious modern golden triangle of prisoners, prisons, and profits.

The judge reassigned another Public Defender from the same office to represent me. The trial was rescheduled for September 17, 1998. Observing the blatant efforts (or lack thereof) of the state to rubber stamp the rest of my life behind bars, my father retained private counsel. To help fund his representation, Richard "Mad Dog" (no kidding, that is his nom de guerre) McFadin established the Jon M. Taylor Defense Fund at the First National Bank (121 W. Jackson St., Gallatin, MO 64640). My father also set up an email address at taylor@sulphurcanyon.com to get the word out and provide updates.

Leading up to the June trial date, a brief but furious "Call for Outrage" campaign was patched together to spread the story seeking help. Dozens of letters from across the nation were sent to the governor's office. One writer looking into the story learned that after a year of essentially ignored departmental appeals, the \#2 assault on staff was to be expunged from my records, but I was to be now found guilty of the \#11 contraband violation. Still I am scheduled 
for felony assault and possession prosecution in county court. It just keeps getting better and better.

What scares me the most is how doing time has opened my eyes to the base nature of the system. Disillusionment is disheartening. As my new counsel so emphatically told me, "It is not about justice; it is about power and who has that power."

I have spoken truth to power, and for that effrontery I am on the precipice of perpetual purgatory in a state correctional facility. Some days it just does not pay to put pen to paper.

Jon Marc Taylor received the Nation Institute/I.F. Stone and Robert F. Kennedy student journalism awards for his reporting on "Pell Grants for Prisoners." He is a member of the editorial board of the JPP and can be contacted at: Crossroads Correctional Center, 1115 East Pence Road, Cameron, MO 64429, U.S.A. 